\author{
David Dranove \\ Daniel Kessler \\ Mark McClellan \\ Mark Satterthwaite \\ Working Paper 8697 \\ http://www.nber.org/papers/w8697 \\ NATIONAL BUREAU OF ECONOMIC RESEARCH \\ 1050 Massachusetts Avenue \\ Cambridge, MA 02138 \\ January 2002
}

The views expressed herein are those of the authors and not necessarily those of the National Bureau of Economic Research or the US Government.

(C) 2002 by David Dranove, Daniel Kessler, Mark McClellan and Mark Satterthwaite. All rights reserved. Short sections of text, not to exceed two paragraphs, may be quoted without explicit permission provided that full credit, including $\mathbb{C}$ notice, is given to the source. 
Is More Information Better? The Effects of 'Report Cards' on Health Care Providers

David Dranove, Daniel Kessler, Mark McClellan and Mark Satterthwaite

NBER Working Paper No. 8697

January 2002

JEL No. I1, L5

\begin{abstract}
Health care report cards - public disclosure of patient health outcomes at the level of the individual physician and/or hospital - may address important informational asymmetries in markets for health care, but they may also give doctors and hospitals incentives to decline to treat more difficult, severely ill patients. Whether report cards are good for patients and for society depends on whether their financial and health benefits outweigh their costs in terms of the quantity, quality, and appropriateness of medical treatment that they induce. Using national data on Medicare patients at risk for cardiac surgery, we find that cardiac surgery report cards in New York and Pennsylvania led both to selection behavior by providers and to improved matching of patients with hospitals. On net, this led to higher levels of resource use and to worse health outcomes, particularly for sicker patients. We conclude that, at least in the short run, these report cards decreased patient and social welfare.
\end{abstract}

David Dranove

Kellogg School of Management

Northwestern University

2001 Sheridan Road

Evanston, IL 60208

Mark McClellan

Council of Economic Advisers

17th and Pennsylvania Avenue, NW

Washington, DC 20502

and NBER

markmc@stanford.edu
Daniel Kessler

Graduate School of Business

Stanford University

Stanford, CA 94305

and NBER

fkessler@stanford.edu

Mark Satterthwaite

Kellogg School of Management

Northwestern University

2001 Sheridan Road

Evanston, IL 60208 


\title{
Is More Information Better? The Effects of 'Report Cards' on Health Care Providers
}

\author{
David Dranove** Danie Kessler,** Mark McClellan,*** \\ and Mark Satterthwaite*
}

\begin{abstract}
A bstract
Health care report cards - public disclosure of patient health outcomes at the level of the individual physician and/or hospital - may address important informational asymmetries in markets for health care, but they may also give doctors and hospitals incentives to decline to treat more difficult, severely ill patients. Whether report cards are good for patients and for society depends on whether their financial and health benefits outweigh their costs in terms of the quantity, quality, and appropriateness of medical treatment that they induce. Using national data on Medicare patients at risk for cardiac surgery, we find that cardiac surgery report cards in New York and Pennsylvania led both to selection behavior by providers and to improved matching of patients with hospitals. On net, this led to higher levels of resource use and to worse health outcomes, particularly for sicker patients. We conclude that, at least in the short run, these report cards decreased patient and social welfare.
\end{abstract}

\section{Introduction}

In the past few years, policy makers and researchers alike have given considerable attention to quality "report cards" in sectors such as health care and education. These report cards provide information about the performance of hospitals, physicians, and schools where performance depends both on the skill and effort of the producer and the characteristics of their patients/students. Perhaps the best known health care report card is New York State's publication of physician and hospital coronary artery bypass graft (CABG) surgery

\footnotetext{
${ }^{*}$ Northwestern University; ${ }^{* *}$ Stanford University and NBER; ${ }^{* *}$ Council of Economic Advisers, on leave from Stanford University and NBER. We would like to thank David Becker for exceptional research assistance, Paul Gertler, Paul Oyer, and Patrick Romano for valuable comments, and seminar participants at the Boston University/Veterans Administration Biennial Health Economics Conference, NBER IO Workshop, Northwestern/Toulouse Joint IO Seminar, Stanford University, UCLA, University of Chicago, University of Illinois, University of Texas, University of Toronto, and Yale University for helpful suggestions. Funding from the US National Institutes on Aging and the Agency for Health Care Research and Quality through the NBER is gratefully appreciated. The views expressed in this paper do not represent those of the US Government or any other of the authors' institutions.
} 
mortality rates. Other states and private consulting firms also publish hospital mortality rates. Many private insurers and consortia of large employers use this information when forming physician and hospital networks and as a means of quality assurance.

The health policy community disagrees on the merits of report cards. Supporters argue that they enable patients to identify the best physicians and hospitals, while simultaneously giving providers powerful incentives to improve quality. $^{1}$ Skeptics counter that there are at least three reasons why report cards may encourage providers to "game" the system by avoiding sick and/or seeking healthy patients. First, it is essential for the analysts who create report cards to adjust health outcomes for differences in patient characteristics ("risk adjustment"), for otherwise providers who treat the most serious cases necessarily appear to have low quality. But analysts can only adjust for characteristics that they can observe. Unfortunately, because of the complexity of patient care, providers are likely to have better information on patients' conditions than even the most clinically detailed data base. For this reason, providers may be able to improve their ranking by selecting patients on the basis of characteristics that are unobservable to the analysts but predictive of good outcomes. ${ }^{2}$

Even if providers do not have superior information on patients' condition, they may still have two other reasons to engage in selection. Suppose that the difference in outcomes achieved by low and high quality providers is greater for sick patients. Considerable circumstantial evidence supports this assumption. For example, Capps et al. (2001) find that sick patients are more willing to incur financial and travel costs to obtain treatment from high quality providers, suggesting that sick patients have more to gain from doing so. In this case, low quality providers have strong incentives to avoid the sick and seek the healthy. By shifting their practice toward healthier patients, inferior providers make it difficult for report cards to confidently distinguish them from their high-quality counterparts, because on relatively healthy patients they have almost as good outcomes. In other words, low-quality providers pool with their high-quality counterparts.

Lastly, even if risk-adjustment were correct in expectation terms but incomplete - that is, risk-adjustment produces noisy estimates of true quality - it may not compensate risk-averse providers sufficiently for the downside of treating sick patients. The cost in utility terms to a risk-averse provider of accepting a sick patient would be greater than the cost of accepting a healthy patient, as long as the variance in the unexplained portion of outcomes is greater for the sick than for the healthy. In practical terms, the utility loss from a few bad

\footnotetext{
${ }^{1}$ Dranove and Satterthwaite (1992), which examines price and quality determination in markets where consumers have noisy information about each, identifies sufficient conditions for report cards on quality to lead to long run improvements in welfare. While we do not study long run changes in this paper, there is anecdotal evidence that providers did take steps to boost quality after the publication of report cards in New York.

${ }^{2}$ For example, even if such comorbid diseases as diabetes or heart failure are measured accurately for purposes of adjusting report cards, physicians who treat patients with more severe or complex cases of diabetes or heart failure are still likely to have worse measured performance.
} 
(risk-adjusted) outcomes that drove a provider to the bottom of the rankings, generated bad publicity, and catastrophically harmed his or her reputation exceeds the utility gain from a corresponding random positive shock. ${ }^{3}$ The fact that report cards are often based on small samples further aggravates both of these incentive problems.

In this paper, we develop a comprehensive empirical framework for assessing the competing claims about report cards. We apply this framework to the adoption of mandatory CABG surgery report cards in New York (NY) and Pennsylvania (PA) in the early 1990s. We begin by testing for three potential effects of report cards on the treatment of cardiac illness:

- The matching of patients to providers. If sick patients have more to gain by receiving treatment from high quality providers, then report cards can improve welfare through improved matching of patients to providers. Sick patients disproportionately have an incentive to seek out the best providers. In addition, the best providers have less incentive to shun the sickest patients.

- The incidence and quantity of CABG surgeries. Provider selection can shift the incidence of CABG surgery from sicker to healthier patients. At the same time, the total number of surgeries may go up or down. As clinicians have pointed out, incidence effects can be socially harmful if sicker patients derive the greatest benefit from bypass surgery (e.g., Topol and Califf 1994, note 21). On the other hand, they may be socially constructive, if the equilibrium distribution of intensive treatment in the absence of report cards is too heavily weighted toward sicker patients.

- The incidence and quantity of complementary and substitute intensive cardiac procedures. For example, a report-card induced decrease in CABG surgeries for sick patients could lead to a shift towards other substitute revascularization procedures, such as angioplasty (PTCA). However, if doctors and hospitals institute processes to avoid mortality from invasive cardiac procedures generally, then a report-card induced decrease in CABG could be accompanied by a decrease in PTCA. In this case, report-card induced decreases in therapeutic procedures such as CABG and PTCA would be accompanied by decreases in complementary diagnostic procedures such as cardiac catheterization $(\mathrm{CATH})$. This too could be welfare-improving or reducing, depending on the consequences of the changing mix of treatment for health care costs and patient health outcomes.

Then, we measure the net consequences of report cards for health care expenditures and patients' health outcomes.

We use a difference-in-difference (DD) approach to estimate the short-run effects of report cards in the population of all U.S. elderly heart attack (AMI)

\footnotetext{
${ }^{3}$ Dziuban et al. (1994) present a case study focusing on physicians' concerns about the incentives for selection generated by prediction errors in the New York CABG report card.
} 
patients and all elderly patients receiving CABG from 1987 through 1994 . We estimate the effect of report cards to be the difference in trends after the introduction of report cards in NY and PA relative to the difference in trends in control states. We find that report cards improved matching of patients with hospitals, increased the quantity of CABG surgery and changed its incidence from sicker patients towards healthier patients, and reduced the quantity of PTCA. Overall this led to higher costs and a deterioration of outcomes, especially among more ill patients. We therefore conclude that the report cards were welfare-reducing.

This analysis hinges on two key assumptions. First, we assume that the adoption of report cards is uncorrelated with unobserved state-level trends in the treatments, costs, and outcomes of cardiac patients. Second, we assume that AMI patients are a relevant at-risk population for CABG, but that unlike the population of patients who actually receive CABG, the composition of the AMI population is not affected by report cards. We explore the validity of these assumptions below.

The paper proceeds as follows. Section 2 discusses some of the institutional history behind health care quality report cards and summarizes previous research about their effects. Section 3 presents our empirical models. It describes in detail how we test for the presence of matching, incidence, and quantity effects and how we identify the consequences of report cards for treatment decisions, costs, and outcomes. Section 4 discusses our data sources. Section 5 presents our results and section 6 concludes by discussing the generalizability and implications of our findings.

\section{Background and Previous Research}

B rief history. Prior to 1994, the federal government and several states produced a variety of health care quality report cards. ${ }^{4}$ Of these, only NY and PA had mandatory, public report cards that utilized clinical information beyond that recorded in generic hospital discharge abstracts. Both these states reported outcomes for patients receiving CABG. (PA later developed a report card on AMI patients' outcomes.) The U.S. Health Care Financing Administration (HCFA) in 1986, followed by several other states including California and Wisconsin, implemented discharge-abstract based reporting systems based either on populations with specific illnesses or on populations receiving one or more procedures, or on both. Since the national HCFA report card preceded state-level report cards and since discharge-abstract based report cards are more likely to suffer from noise and bias problems (e.g., Romano et al. 1999, Romano and Chan 2000), the discharge-abstract based report cards states produced are unlikely to have had noticeable effects on patient and provider behavior during our study period. ${ }^{5}$

\footnotetext{
${ }^{4}$ See Iezzoni $(1994,1997 \mathrm{a})$ and Richards (1994) for a discussion of some of these initiatives. Mennemeyer, Morrisey, and Howard (1997) contains a detailed discussion of HCFA's reporting efforts.

${ }^{5}$ We check this modeling assumption below by exploring how treatment in states with discharge-abstract based reporting differed from treatment in New York and Pennsylvania
} 
For these reasons, our principal analysis treats NY and PA as the two "treatment" states. Beginning in December of 1990, the NY Department of Health released publicly hospital-specific data on raw and risk-adjusted mortality of patients receiving CABG surgery in the previous year. Beginning in 1992, NY also released surgeon-specific mortality (Chassin, Hannan, and DeBuono 1996). Beginning in November of 1992, the PA Health Care Cost Containment Council published hospital- and surgeon-specific data on risk-adjusted CABG mortality (PA Health Care Cost Containment Council 1998). This would suggest that report cards could have begun to affect decision-making in NY in 1991 and in PA in 1993, though an alternative hypothesis is that a 1993 effective date is also appropriate for NY because the NY report card did not list individual surgeon information until then.

Previous research. The existing empirical literature provides mixed evidence on the consequences of report cards. One arm of the literature uses surveys of patients and clinicians to assess the consequences of report cards. Although some surveys suggest that report cards have little effect on decision-making (e.g., Schneider and Epstein 1998; see Marshall et al. 2000 for an excellent catalogue and description of this work), other surveys reach the opposite conclusion. For example, in one survey, 63 percent of cardiac surgeons reported that, as a consequence of the report cards' introduction, they only accepted healthier candidates for CABG surgery . Cardiologists confirmed this, with 59 percent reporting that report cards made it more difficult to place severely ill candidates for CABG (Schneider and Epstein 1996).

Another arm of the literature uses analysis of clinical and administrative data, almost entirely from NY's report card, to reach a very different conclusion: it finds that report cards led to dramatic improvements in the quality of care (Hannan et al. 1994; Peterson et al. 1998). Several researchers document the mechanism through which this may have occurred, including inducing poorlyrated hospitals to change patterns of care (Dziuban et al. 1994) and enabling highly-rated physicians and hospitals to increase their market shares (Mukamel and Mushlin, 1998).

The optimistic findings of these NY studies must be tempered by the potential presence of incidence effects due to provider selection, an issue that studies such as Green and Wintfeld (1995), Schneider and Epstein (1996), Leventis (1997), and Hofer et al. (1999) suggest may be of more than academic concern. If providers perform CABG on disproportionately fewer sick patients and if sicker patients benefit more from $\mathrm{CABG}$, then the mortality rate among patients who would have received CABG in the absence of report cards can increase, even as the observed CABG mortality rate falls. The failure of previous studies to consider the entire population at risk for CABG, rather than only those who receive it, is a potentially severe limitation. Furthermore, none of these studies assess the impact of report cards on the resources used to treat CABG patients. Even if report cards reduce mortality, they may not be socially constructive if they do so at great financial cost.

and from that in other states. 


\section{Empirical Models}

We examine the effects of the mandatory CABG surgery report card laws adopted by NY and PA in the early 1990s. To identify matching, incidence, and quantity effects, we study cohorts of AMI patients and cohorts of patients receiving CABG who may or may not have had AMI. We make two key assumptions. First, we assume that CABG report cards do not affect the composition of the population hospitalized with AMI, especially in the short run. The reason is that AMI is a medical emergency that, unless immediately fatal, generally results in hospitalization, almost always in the hospital at which the patient initially presented. We explore the validity of this assumption below. In contrast, report cards can affect the population who receives CABG because it is an elective procedure in the vast majority of cases (Weintraub et al, 1995; Ho, 1989).

Second, we assume that AMI patients are a relevant at-risk population for CABG, and therefore likely to be affected by the adoption of report cards. CABG is an important treatment for AMI: in 1994, $16 \%$ of elderly AMI patients will get CABG (for non-elderly AMI patients, this number is $20 \%$ or higher); AMI patients also represent a significant portion of CABG operations (approximately $25 \%$ in the elderly in 1994). Possibly more importantly, a provider's skill at CABG is likely to be correlated with her skill at other important treatments for AMI. Thus, the quality information provided by report cards may lead sicker AMI patients to be more willing than healthier patients to incur financial or other costs to obtain treatment from a high-quality provider.

We estimate two types of empirical models. The first type takes the hospital as the unit of analysis and assesses the effects of report cards on the incidence of CABG and the matching of patients to hospitals. To determine the effect on incidence, we estimate the extent to which the trend over time in the mean health status of CABG patients in NY and PA hospitals differed from the trend in hospitals in comparison states. We then compare the DD estimates with DD estimates for all AMI patients, to investigate whether differential trends in the health status of CABG patients merely reflect differential trends in the overall population of elderly patients with cardiac illness. To determine report cards' effect on the match of patients with hospitals, we investigate whether report cards led to greater within-hospital homogeneity of patients in NY and PA. A reduction in the within-hospital variation in patients' health status on admission in NY and PA hospitals relative to hospitals in comparison states is consistent with improved matching.

The second type of empirical model takes the patient as the unit of analysis and assesses the effect of report cards on both (i) the quantity and incidence of CABG and other intensive cardiac treatments and (ii) the resource use and health outcomes that determine the net consequences of report cards for social welfare. In these models, report cards affect the quantity of CABG surgery (or PTCA or CATH) if they affect the probability that an AMI patient receives CABG (or PTCA or CATH). These models also provide an alternative assessment of incidence effects. Report cards affect the incidence of CABG (or 
PTCA or CATH) if, within the population of AMI patients, report cards have a differential effect on the probability of CABG (or PTCA or CATH) for sick versus healthy patients. Finally, these patient level models allow an assessment of report cards' effects on cost and outcomes.

\subsection{Hospital Level Analysis}

To test for incidence and matching effects at the hospital level, we use comprehensive individual-level Medicare claims data (described below) to calculate the average illness severity of patients that are admitted to each hospital for CABG surgery. To test for incidence effects, we estimate regressions of the form

$$
\begin{aligned}
\ln \left(h_{\mathrm{lst}}\right)= & A_{\mathrm{s}}+B_{\mathrm{t}}+g \cdot Z_{\mathrm{lst}} \\
& +p \cdot L_{\mathrm{st}}+q \cdot N_{\mathrm{st}}+e_{\mathrm{lst}},
\end{aligned}
$$

where

$l$ indexes hospitals, $s$ indexes states, and $t$ indexes time, $t=1987, \ldots, 1994$

$h_{\mathrm{Ist}}$ is the mean of the illness severity before admission or treatment of hospital l's elderly Medicare CABG patients

$A_{\mathrm{s}}$ is a vector of 50 state fixed effects

$B_{\mathrm{t}}$ is a vector of 8 time fixed effects

$Z_{\text {Ist }}$ is a vector of hospital characteristics, including indicator variables for rural location, medium (100-300 beds) and large size ( $>300$ beds) (omitted category is small size), two ownership categories (public and private forprofit, omitted category is private non-profit), and teaching status

$L_{\mathrm{st}}=1$ if hospital is in NY on or after 1991, or in PA on or after 1993, 0 otherwise

$N_{\mathrm{st}}$ is the number of hospitals, and its square and cube, in state $s$ at time $t^{6}$

$e_{\mathrm{Ist}}$ is an error term.

We weight each hospital (observation) by the number of CABG patients admitted to it. The coefficient $p$ is the DD estimate of the effect of report cards on the severity of patients who receive CABG. If $p<0$, then report cards have caused a shift in incidence from sicker to healthier patients.

To confirm that this is not an artifact of differential trends in the health or care of those elderly cardiac patients who reside in NY and PA, we also examine

\footnotetext{
${ }^{6}$ We include the number of hospitals in the state as a coarse control for provider participation. If report cards reduce the number of hospitals in a state, they would increase the measured dispersion of patients' health histories at the remaining hospitals, even in the absence of any true effect of report cards on dispersion. Our results do not change if we exclude this variable from the analysis.
} 
the trends for AMI patients. Though at risk for CABG, these patients are not subject to selection. We reestimate (1) using the mean illness severity of AMI patients as the dependent variable and compare this DD estimate to the DD estimate for CABG patients.

We also calculate the within-hospital coefficient of variation (CV) of the illness severity before treatment of each hospital's CABG and AMI patients. Improved sorting of patients among hospitals would cause the average withinhospital CV of severity to decline in NY and PA relative to other states (provided the mean of severity does not increase). We therefore reestimate (1) using the within-hospital CVs as dependent variables; an estimated $p<0$ is then consistent with improved patient sorting.

Report-card induced matching should also lead high-quality hospitals to treat an increasing share of more severely ill patients. Since true quality is not observable, and indeed may not be measured accurately by a selectioncontaminated CABG report card, we cannot test this hypothesis directly. However, we can examine whether the effect of report cards varies with hospital characteristics that are likely to be correlated with true quality, such as teaching status. Returning to equation (1), let $h_{\text {Ist }}$ again be the mean of the illness severity of hospital l's CABG and AMI patients and define $Z_{\text {lst }}^{\text {TEACH }}$ to be an indicator variable denoting whether hospital $l$ is a teaching hospital. Estimate (1) with the interaction $Z_{\text {Ist }}^{\text {TEACH }} * L_{\text {st }}$ included. If $r>0$, where $r$ is the estimated coefficient on the interaction, then report cards lead more severely ill patients to be treated at teaching hospitals.

\subsection{Patient Level Analysis}

We also use Medicare claims data to form a cohort of individual AMI patients. This cohort contains information on (i) illness severity in the year before treatment, (ii) the overall intensity of treatment in the year after admission, (iii) whether the individual patient received CABG surgery, PTCA, or CATH in the year after admission for AMI, and (iv) all-cause mortality and cardiac complications such as readmission for heart failure (HF) in the year after admission. To test for a quantity effect on CABG surgery, we estimate the regression

$$
C_{\mathrm{kst}}=A_{\mathrm{s}}+B_{\mathrm{t}}+g \cdot Z_{\mathrm{kst}}+p \cdot L_{\mathrm{st}}+e_{\mathrm{kst}}
$$

where

$k$ indexes patients, $s$ indexes states, $t$ indexes time $t=1987, \ldots, 1994$

$C_{\text {kst }}$ is a binary variable $=1$ if patient $k$ from state $s$ at time $t$ received CABG surgery within one year of admission to the hospital for AMI

$A_{\mathrm{s}}$ is a vector of 50 state fixed effects

$B_{\mathrm{t}}$ is a vector of 8 time fixed effects 
$Z_{\mathrm{kst}}$ is a vector of patient characteristics, including indicator variables for rural residency, gender, race (black or nonblack), age (70-74, 75-79, 80-89, and 90-99, omitted group is 65-69), and interactions between gender, race and age

$L_{\mathrm{st}}=1$ if patient $k$ 's residence is in NY on or after 1991, or in PA on or after 1993, 0 otherwise

$e_{\mathrm{kst}}$ is an error term.

A positive $p$ implies that report cards increased the probability that an AMI patient receives CABG. We measure the quantity effects of report cards on the alternative intensive treatments PTCA and CATH by reestimating equation (2) for these treatments instead of CABG.

Our approach to measuring the effect of report cards on outcomes and costs follows the same line. Let $O_{\text {kst }}$ be a binary variable equaling 1 if patient $k$ from state $s$ at time $t$ experienced an adverse health outcome (e.g., HF) and let $y_{\text {kst }}$ be his total hospital expenditures in the year after admission with AMI. Reestimate (2) with $O_{\mathrm{kst}}$ substituted as the dependent variable. If $p>0$, then report cards increase the incidence of that adverse outcome. Similarly, if the model is run with $\ln \left(y_{\mathrm{kst}}\right)$ as the dependent variable, then $p>0$ implies that report cards increase expenditures.

To assess the effect of report cards on social welfare, we compare estimates of the effect of report cards on the total resources used to treat a patient with AMI to the effect of report cards on AMI patients' health outcomes. If report cards uniformly increase adverse outcomes and increase costs, then we conclude that their effect on social welfare is negative. If report cards uniformly decrease adverse outcomes and decrease costs, then we conclude that their effect on social welfare is positive. If report cards lead to greater resource use and improved outcomes (or reduced resource use and worse outcomes), then we can calculate the "cost effectiveness" of report-card induced (or report-card restrained) treatment.

Patient level analysis also permits an alternative assessment of incidence effects. To compare the effects of report cards on sick versus healthy patients, we estimate models that include a control for patients' illness severity before treatment and its interaction with $L_{\mathrm{st}}$ :

$$
\begin{aligned}
\ln _{\mathrm{kst}}\left(y_{\mathrm{kst}}\right)_{\mathrm{kst}}{ }^{3 / 4}= & A_{\mathrm{s}}+B_{\mathrm{t}}+g \cdot Z_{\mathrm{kst}}+p \cdot L_{\mathrm{st}} \\
& +q \cdot w_{\mathrm{kst}}+r \cdot L_{\mathrm{st}} \cdot w_{\mathrm{kst}}+e_{\mathrm{kst}},
\end{aligned}
$$

where $w_{\text {kst }}$ is a measure increasing in patient $k$ 's illness severity. If this model is estimated with $C_{\mathrm{kst}}$ as the dependent variable, than an estimate of $r \neq 0$ implies report cards altered the incidence of CABG surgery.

In order to replicate the results in the previous literature, we also use the claims data to form a cohort of patients receiving CABG whether or not they had AMI, and estimate equations (2) and (3). 


\section{Data}

We use data from two sources. First, we use comprehensive longitudinal Medicare claims data for the vast majority of individual elderly beneficiaries who were admitted to a hospital either with a new primary diagnosis of AMI or for CABG surgery from 1987-1994. The AMI sample is analogous to that used in Kessler and McClellan (2000), but extended to include rural patients. Patients with admissions for AMI in the prior year were excluded from the AMI cohort. For each individual patient, as a measure of the patient's illness severity before treatment, we calculate total inpatient hospital expenditures for the year prior to admission. We measure the intensity of treatment that the patient receives as total inpatient hospital expenditures in the year after admission. Measures of hospital expenditures were obtained by adding up all inpatient reimbursements (including copayments and deductibles not paid by Medicare) from insurance claims for all hospitalizations in the year preceding or following each patient's initial admission. We also calculate for each patient the total number of days in the hospital in the year prior to admission as an additional measure of illness severity.

We construct three measures of important cardiac health outcomes. Measures of the occurrence of cardiac complications were obtained by abstracting data on the principal diagnosis for all subsequent admissions (not counting transfers and readmissions within 30 days of the index admission) in the year following the patient's initial admission. Cardiac complications included rehospitalizations within one year of the initial event with a primary diagnosis (principal cause of hospitalization) of either subsequent AMI or heart failure (HF). Treatment of cardiac illness is intended to prevent subsequent AMIs, and the occurrence of HF requiring hospitalization is evidence that the damage to the patient's heart from ischemic disease has had serious functional consequences. Data on patient demographic characteristics were obtained from the Health Care Financing Administration's HISKEW enrollment files, with death dates based on death reports validated by the Social Security Administration.

Our second principal data source is comprehensive information on U.S. hospital characteristics that the American Hospital Association (AHA) collects. The response rate of hospitals to the AHA survey is greater than 90 percent, with response rates above 95 percent for large hospitals ( $>300$ beds). Because our analysis involves Medicare beneficiaries with serious cardiac illness, we examine only nonfederal hospitals that ever reported providing general medical or surgical services (for example, we exclude psychiatric and rehabilitation hospitals from analysis). To assess hospital size, we use total general medical/surgical beds, including intensive care, cardiac care, and emergency beds. We classify hospitals as teaching hospitals if they report at least 20 full-time residents.

Our hospital-level analysis matches the AHA survey with hospital-level statistics calculated from the Medicare cohorts. We use patient-level illness severity before admission or treatment as measured by total hospital expenditures and

total number of days in the hospital in the year before admission or treatment to calculate for each hospital the within-hospital CV and mean of these two 
variables. We use the CV of patients' historical expenditures to measure the dispersion of severely ill patients because the CV is invariant to proportional shifts in the distribution of historical expenditures. However, the CV is not invariant to constant-level shifts in the distribution. Thus, interpretation of the estimated effect of report cards on the within-hospital CV of severities as a measure of the degree of sorting of patients across hospitals depends on how report cards shift the distribution of severities. This is likely to be more important in the CABG cohort than in the AMI cohort, because provider selection behavior is more likely to affect the distribution of illness severities of patients receiving CABG than it is to affect the distribution of severities of AMI patients.

Appendix tables 1 and 2 present descriptive statistics for hospitals and patients, respectively, for the full set of control variables and outcomes used in our analysis. As reported in appendix table 1, hospitals subject to report cards (i.e., those in New York and Pennsylvania) account for roughly 14 percent of all hospitals. The CV of patient expenditures and patient days in the year prior to admission is between 1.5 and 2.5, indicating that most hospitals treat patients with heterogeneous medical histories. As reported in appendix table 2, AMI patients averaged between $\$ 2690$ (1987) and $\$ 2977$ (1994) in real 1995-dollar hospital expenditures in the year prior to admission. These expenditures, however, were concentrated in a small subset of patients. Expenditures in the pooled 1987-94 AMI population become nonzero at the 71st percentile, and reach $\$ 9135$ at the 90th percentile. CABG patients were slightly sicker in terms of prior hospital utilization (with historical expenditures averaging \$3771-\$4431), reflecting the fact that they were all undergoing a procedure intended to treat serious cardiac illness. The relative trend in the health status of CABG versus AMI patients was strikingly different. While prior year's hospital expenditures for the AMI population was rising, prior year's expenditures for the CABG population was falling - and the number of patients receiving CABG was rising dramatically as well. Over the 1980s and 1990s, CABG surgery was diffusing to an increasing number of healthier patients.

\section{Results}

Table 1 presents inflation-adjusted mean hospital expenditures in the year prior to entry into our study cohorts of all AMI and CABG patients from 1990 (prior to report cards) and 1994 (after report cards). Recall that mean expenditures in the year prior to admission is an indicator of that cohort's health status i.e., lower expenditures implies a healthier cohort. Table 1 previews our basic result - report cards led to a dramatic shift in the incidence of intensive cardiac treatment. The data in the first three columns of Table 1 show that the prior year's expenditures for AMI patients in NY and PA increased roughly 8.5 percent. Expenditures in all other states increased by 9.4 percent, and in the neighboring states of CT, MD, and NJ, expenditures grew by 8.6 percent. These data reflect a nationwide increase in treatment intensity for elderly patients with cardiac illness. There is no evidence of a differential change across states in 
the illness severity of AMI patients, consistent with our assumption that report cards did not affect the composition of this population.

Trends in the hospitalization history of patients receiving CABG surgery looked quite different. Mirroring appendix table 2, the average growth in the prior year's expenditures of the average CABG patient (with or without AMI) was substantially smaller: CABG was diffusing to healthier patients. But the extent to which the incidence of CABG surgery shifted toward healthier patients differed dramatically across areas. In NY and PA, the prior year's hospital expenditures of CABG patients (with or without AMI) fell; in all other states, the prior year's expenditures rose; in the states neighboring NY and PA, the prior year's expenditures fell, but by a much smaller amount.

The adoption of report cards in NY and PA coincided with a substantial decline in the relative illness severity of CABG versus AMI patients, as compared to the change in illness severity of CABG versus AMI patients in a "control" group of states. This is compelling evidence that the incidence of CABG surgery in NY and PA shifted towards healthier patients relative to incidence trends in comparison states.

\subsection{Hospital Level Analysis: Testing for Incidence and Matching Effects}

Table 2 confirms that report cards led to a shift in the incidence of CABG surgery towards healthier patients and provides evidence of enhanced matching of patients to hospitals. The estimates in the table are the result of four sets of regressions, each with a different dependent variable. The unit of analysis for the regressions is the hospital/year. Each table entry represents the coefficient and standard error (corrected for heteroscedasticity and within state/time cell error correlation) on the dummy variable $L_{\text {st }}$, "Report Card Present in State," from a different model. All values have been multiplied by 100 to facilitate interpretation as percentages. We report results for two different dates for the effect dates of report cards: (i) 1991 in NY and 1993 in PA and (ii) 1993 in both states.

The top two rows of table 2 show that report cards led to a decline in the illness severity of patients receiving CABG surgery, but not in the illness severity of patients with AMI. Report cards are associated with declines of 2.43 to 5.30 percent (columns one and two) in the illness severity of CABG patients from NY and PA relative to all other states. No such effect was present among AMI patients from NY and PA (columns three and four). Indeed, the DD estimate of report cards on AMI patients' health status before admission is weakly positive, although this is only statistically significant for the earlier NY effective date.

The bottom two rows of Table 2 suggest that report cards led to greater matching of patients to hospitals on the basis of patients' health status on admission. Column three shows that among AMI patients, which is the cohort that providers can not shape through selection, report cards led to more homogeneous cardiac patient populations within hospitals: the CV of AMI patients' health histories declined significantly in NY and PA versus everywhere else. 
Column one shows a different story among CABG patients: the CV of CABG patients' historical expenditures increased and the CV of CABG patients' days in the hospital was roughly unchanged. These coefficients, however, are not straightforwardly interpretable as a measure of the effect of report cards on matching in the CABG cohort because (as just discussed) report cards led to a substantial decline in the mean of the distribution of CABG patients' illness severities. This by itself increases the CV. If we assume that the mean illness severity of CABG patients in NY and PA would have been equal to that of AMI patients but for report-card induced changes in the incidence of CABG surgery, then the difference in trends in the CV of CABG patients' health histories are also consistent with better matching. Depending on the particular model chosen, the difference between the DD estimate of report cards on the mean illness severity of CABG patients and AMI patients was 3.5 to 7 percentage points. Subtracting this from the DD estimate of the effect of report cards on the CV of CABG patients' health histories (because $\ln \mathrm{CV}=\ln \sigma-\ln \mu$ ) leads in every specification to a negative net effect. ${ }^{7}$

Table 3 documents the presence of another predicted consequence of reportcard induced matching: that an increased proportion of more severely ill patients would obtain treatment at high-quality hospitals. Since true hospital quality is very difficult to observe and patient selection may contaminate report card rankings of quality, we use teaching status as a proxy for quality. The results in the first and second columns show that, in spite of the aggregate decline in the illness severity of CABG patients in NY and PA, the illness severity of CABG patients at teaching hospitals in those states remained roughly constant. The results in the third column shows that report cards did not change the average severity of AMI patients in the non-teaching hospitals of NY and PA. But, according to the fourth column, after the publication of report cards began, the average severity of these patients among NY and PA teaching hospitals increased substantially. ${ }^{8}$

\subsection{Patient Level Analysis: Testing for Quantity and In- cidence Effects}

Table 4 presents our analysis of the quantity and incidence effects of report cards on three important intensive treatments received by AMI patients: CABG, PTCA, and CATH. We report regressions horizontally in pairs for a given dependent variable: the first row of a pair presents estimates from equation (2) and the second presents estimates from equation (3). Estimated coefficients for other covariates are not reported so as to make it easier to view the main results.

\footnotetext{
${ }^{7}$ As a second, direct test of the matching hypothesis, we estimated the effect of report cards on the standard deviation of historical patient expenditures and lengths-of-stay in the AMI population. We found that report cards statistically significantly decrease the log of the within-hospital standard deviation of patients' historical length of stay, although they do not significantly decrease the log of the within-hospital standard deviation of patients' historical expenditures.

${ }^{8}$ We reestimated these models with controls for the competitiveness of hospital markets as calculated in Kessler and McClellan (2000, 2001), which did not change the results.
} 
Table 4 contains three key findings. First, report cards led to an increase in the quantity of CABG surgery, and that increase was confined to healthier patients. Second, report cards led to a decrease in PTCA, for both sick and healthy patients. Third, report cards led to increased delays in the execution of all three intensive treatments, significantly reducing the probability that an AMI patient would receive CABG, PTCA, or CATH within one day of admission.

In particular, report cards increase the probability that the average AMI patient will undergo CABG surgery within 1 year of admission for AMI by 0.60 or 0.91 percentage points, depending on the assumed effective date of report cards. These quantity effects are considerable, given that the probability of CABG within one year for an elderly AMI patient during our sample period was 13.1 percent. $^{9}$ Consistent with Table 2 's results on incidence, the quantity increase was entirely accounted for by surgeries on less severely ill patientsthose who did not have a hospital admission in the year prior to their AMI. ${ }^{10}$ This increase in CABG quantity was accompanied by increased time from AMI to CABG: at least for healthier patients, the DD estimate of the effect of report cards on the one-day CABG rate was negative and strongly significant.

Report cards also led to substantial reductions in the quantity of other intensive cardiac treatments, for both relatively healthy and sick patients. The use of PTCA, an alternative revascularization procedure, fell dramatically in NY and PA relative to other states. The one-year angioplasty rate for all AMI patients fell significantly: depending on specification, by 1.69 or 1.22 percentage points, on a base of 12.43 percentage points. For sick patients, the one-year angioplasty rate fell significantly as well: depending on specification, by 1.50 or 1.72 percentage points. ${ }^{11}$ Essentially identical results obtain for the thirty-day and one-day PTCA rates. Although report cards did not affect the one-year CATH rate, they led, for both sick and healthy patients, to statistically significant declines in the one-day CATH rate, a measure of the rate at which patients are on a rapid track for subsequent intensive therapeutic treatment. ${ }^{12}$

Unlike for CABG, we found no strong pattern of how report cards changed the incidence of PTCA and CATH. Except for the one-day rates, the effect of report cards on the quantities of PTCA and CATH was roughly similar for sick versus healthy patients. For both PTCA and CATH, there is some indication

\footnotetext{
${ }^{9}$ The proportion of AMI patients that had been hospitalized in the year prior to admission is 0.292 . The left-hand column of table 4 reports that (i) $14.76 \%$ of AMI patients who had not been hospitalized the previous year received CABG within one year of admission and (ii) $9.10 \%$ of AMI patients who had been hospitalized the previous year received CABG within one year of admission. Therefore the base rate is $0.708 * 14.76+0.292 * 9.10=13.1 \%$.

${ }^{10}$ The effect of report cards on more severely ill patients' probability of CABG surgery is the approximately zero sum of the report cards' direct effect and the interaction effect prior year admission.

${ }^{11}$ This is the sum of column one and column two's coefficients: $-1.50=-1.73+.20 ;-1.72=$ $-.96-.76$. Heteroscedasticity-consistent standard errors for sick patients corrected for within state/time cell correlation (not reported in the table) are 0.49 and 0.41 , for the results in the left and right panels of the table, respectively.

${ }^{12}$ Heteroscedasticity-consistent standard errors for sick patients one-day catheterization rate corrected for within state/time cell correlation not reported in the table are 0.70 and 0.63 , for the results in the left and right panels of the table, respectively.
} 
that the decline in their one-day rates was larger for healthy patients than sick patients.

\subsection{Patient Level Analysis: Testing for Outcomes and Welfare Effects}

Table 5 presents estimates of the effects of report cards on hospital expenditures, readmission with cardiac complications, and mortality in the year after initial admission. The first row shows that the shifts in treatment behavior documented in table 4 led to higher levels of hospital expenditures for the average AMI patient. This is understandable, considering that the average patient is more likely to undergo costly CABG surgery. Surprisingly, however, report cards also led to increased expenditures for the most severely ill patients (second row), despite the fact that they were no more likely to receive CABG and were less likely to receive PTCA. The bottom six rows of table 5 present estimates of the effects of report cards on patient health outcomes. They show that report cards increased significantly the average rate of readmission with heart failure by approximately 0.5 percentage points. They also provide statistically marginal evidence that the average mortality rate in NY and PA increased by 0.45 percentage points on a base of 33 percent.

Much more striking, however, is the differential effect of report cards on healthy vs. sick AMI patients. In spite of report-card induced additional CABG surgeries, less ill AMI patients experienced no statistically significant health benefits. In contrast, among AMI patients with a prior year's inpatient admission, report cards led to statistically significant, quantitatively substantial increases in adverse outcomes. Relatively sicker patients experienced higher rates of readmission with heart failure (approximately 2.3 percentage points greater, on a base heart-failure readmission rate of 9.4 percent) and higher rates of recurrent AMI (approximately 0.5 percentage points greater, on a base of 5.5 percent). This helps explain the expenditure increase reported above. Finally, in one specification, sicker patients experienced a 0.82 percentage point statistically significantly higher mortality rate in the report card states; in the other specification, this effect is not significant. ${ }^{13}$

Taken together, our results show that report cards led to increased expenditures for both healthy and sick patients, no health benefits for healthy patients, and adverse health consequences for sicker patients. Thus we conclude that report cards reduced our measure of welfare over the time period of our study.

\subsection{Validity Checks}

Table 6 presents estimates based on alternative models of the effects of report cards on key treatment decisions, expenditures, and health outcomes. The left panel of Table 6 reports the estimated effects of report cards using only NJ,

\footnotetext{
${ }^{13}$ The reported estimate equals the sum of the main effect $(0.13)$ and the interacted effect (0.69).
} 
CT, and MD (instead of all other states) as the "control" group. Although the statistical significance of some of the effects declines, the basic findings remain intact. Report cards led to a shift in the incidence of CABG from relatively sick to healthy patients. Indeed, using the alternative control group, the quantity of CABG surgeries received by healthier patients increased by a significant 0.98 percentage points while the quantity received by sick patients declined by a significant 0.96 percentage points as a result of the introduction of report cards. ${ }^{14}$ The one-year PTCA and one-day CATH rates for sick patients also declined significantly, by 2.00 and 2.09 percentage points, respectively. ${ }^{15}$ Although the expenditure consequences of report cards are smaller in magnitude and insignificant in this alternative model, the adverse outcome consequences for sick patients remain significant and large.

The right panel of table 6 reports the estimated DD effects of report cards in models that include a separate linear time trend $(1987=0)$ for NY and PA as well as the full set of state- and time-fixed effects that are present in all the other models. Its purpose is to determine whether the estimates from Tables 4 and 5 are due to an underlying differential trend in treatment of cardiac patients in report card versus all other states. Although including controls for a preexisting trend for report card states absorbs the differential trends in treatments in report card states versus other areas, it does not absorb the differential trend in either expenditures or health outcomes. These slightly weaker results are not surprising given the correlation between the time trend and the indicator for the presence of report cards in NY and PA.

We also reestimated, but do not report results from, equations (2) and (3) including additional controls for the discharge-abstract based report cards in California (effective 1994) and Wisconsin (effective 1991). As discussed above, our principal analysis does not assess the effect of the state discharge-abstract based report cards because it is unlikely that they would have had important effects on treatment decision-making during our study period: HCFA dischargeabstract based report cards were present in every state from the start of our study period through mid-1992. The CA and WI report cards differed from the NY and PA report cards in that they reported mortality by illness, not by operative procedure. The estimated DD effects of the NY/PA report cards in a model with additional controls for CA/WI report cards are virtually unchanged from the estimates in Table 4. In addition, we did not find robust evidence of incidence or quantity effects from CA/WI report cards, although AMI patients in CA and WI showed a statistically significant 0.6 percentage point decline in heart failure rates after versus before report cards, relative to that in other non-report card states over the same period.

In other results not included in the tables, we explored the validity of the assumption of exogeneity of the AMI cohort to states' adoption of report cards, i.e., whether report cards affected the selection of patients with AMI across

\footnotetext{
${ }^{14}$ Calculated as the sum of the column one and three coefficients: $0.96=.98-1.94$. Its standard error, which is not reported in the table, is 0.47 .

${ }^{15}$ The standard errors for these two sums, which are not reported in the table, are 0.58 and 0.93 respectively.
} 
states and over time. First, we investigated whether trends in AMI incidence among individuals 65 and over differed in NY and PA in order to provide a rough check that report cards did not affect selection into the AMI cohort. The point estimate of the effect of report cards on AMI incidence was minuscule (between two and three orders of magnitude smaller than the average AMI incidence in this period) and insignificant. Second, we investigated whether the estimated effects in tables 2 and 3 are due to a differential decline in the state-level CV of AMI patients' illness severities in NY and PA. Unreported DD estimates of the effect of report cards on $\ln ($ state/year average $\mathrm{CVs}$ of year-prior expenditures) are very small and insignificant.

Table 7 is similar to table 5 , but reports estimates of equations (2) and (3) for the population of CABG patients rather than the population of AMI patients. It shows that applying the methods of the previous literature to our population of elderly CABG patients approximately replicates the findings of that literature. The overall health status of CABG patients appears to improve as a result of report cards, with significantly lower rates of AMI and mortality. Our DD estimate of the effect of report cards on 1-year mortality of about 1 percentage point is similar to the DD estimate of the effect of NY's report cards on 30day mortality of 0.7 percentage points that Peterson et al. (1998) presented. Table 7 further shows that there appear to be no consistent adverse differential effects of report cards by illness severity. While this is consistent with the findings in Peterson et al. (1998) and Hannan et al (1994), we offer a different explanation: observed mortality declined as a result of a shift in incidence of CABG surgeries toward healthier patients, not because CABG report cards improved the outcomes of care for individuals with heart disease.

\section{Conclusion}

Is the publication of information on health outcomes of physicians and hospitals constructive or harmful? In markets for health care, which exhibit important asymmetries of information and substantial heterogeneity of providers, patientbackground adjusted hospital mortality rates would appear to enable patients to make better-informed hospital choices and to give providers the incentive to make appropriate investments in delivering quality care. On the other hand, mandatory reporting mechanisms inevitably give providers the incentive to decline to treat more difficult and complicated patients. Doctors and hospitals likely have more detailed information about patients' health than can the developer of a report card, allowing them to choose to treat unobservably (to the analyst) healthier patients. And even if they do not, providers' risk aversion and low-quality providers' desire to pool with their high-quality counterparts may lead them to engage in selection behavior. For these reasons, the net consequences of report cards for patient and social welfare are theoretically indeterminate. Report cards may be either welfare reducing or enhancing, depending on the extent of provider selection and the appropriateness of treatment decisions in the absence of report cards. 
We report three key findings. First, the NY and PA CABG surgery report cards led to substantial selection by providers. Report cards led to a decline in the illness severity of patients receiving CABG in NY and PA relative to patients in states without report cards, as measured by hospital utilization in the year prior to admission for surgery. In all specifications, the shift in the incidence of $\mathrm{CABG}$ from sick to healthy took the form of an increase in the quantity of CABG surgery performed on healthier patients; in specifications using the neighboring states of NJ, CT, and MD as the control group, the increase in the quantity of CABG for the healthy was accompanied by a significant decrease in the quantity of CABG for the sick. In addition, report cards led to substantial declines in other intensive cardiac procedures for both relatively healthy and sick AMI patients.

Second, report cards led to increased sorting of patients to providers on the basis of the severity of their illness. In particular, hospitals in New York and Pennsylvania experienced relative declines in the within-hospital heterogeneity of their AMI patient populations, with those two states' teaching hospitals picking up an increasing share of patients with more severe illness. The fact that report cards led to increased delays for both healthy and sick patients in the execution of all three intensive treatments supports our findings of increased selection and increased sorting, because the processes of selection and sorting are likely to take time.

Third, on net, the New York and Pennsylvania report cards reduced our measure of welfare, particularly for patients with more severe forms of cardiac illness. Report cards led to higher levels of Medicare hospital expenditures (although this finding was not statistically significant in specifications using NJ, $\mathrm{CT}$, and MD as a control group) and greater rates of adverse health outcomes. Hospital expenditures post-treatment increased not only for healthier AMI patients, but also for sicker AMI patients. Even as the additional CABG surgeries the healthier patients received failed to lead to substantial health benefits, more severely ill AMI patients experienced dramatically worsened health outcomes. Among more severely ill patients, report cards led to substantial increases in the rate of heart failure and recurrent AMI, and, in some specifications, to greater mortality. The magnitude of the increase in the rate of adverse health outcomes among sick patients is large but plausible, given that it is roughly proportional to the magnitude of the total decrease in the use of the intensive cardiac treatments that we observe, and that it was likely accompanied by other changes in medical practice that we do not observe.

How might we explain these seemingly disparate empirical findings? For healthier patients, doctors and hospitals substituted CABG for PTCA. The shift to CABG from PTCA increased Medicare expenditures, but failed to provide any measurable health benefits. For sicker patients, doctors and hospitals avoided performing both CABG and PTCA, and took longer to deliver the intensive cardiac treatments they ultimately administered. ${ }^{16}$ In response to

\footnotetext{
${ }^{16}$ Although we did not find statistically significant decreases in all specifications in the quantity of CABG for AMI patients with a prior year hospital admission, we did find (in
} 
report cards, hospitals implemented a broad range of changes in marketing, governance, and patient care (Bentley and Nash 1998) that may well have led to greater caution in the utilization of all invasive procedures in sick patients. On net, these changes were particularly harmful. The less effective medical therapies that were substituted for CABG and PTCA, combined with delays in treatment, led sicker patients to have substantially higher frequencies of heart failure and repeated AMIs and ultimately higher total costs of care.

Caution should be exercised in interpreting our results too negatively. First, we only measure short run responses, and long run benefits to quality reporting may be positive and large (e.g., Dranove and Satterthwaite 1992). Our analysis is short run because the data we analyze is, at most, for only the first four years of the Pennsylvania and New York report card programs. This period is short enough that the population and skill distribution of providers likely remained largely fixed. In the longer run, however, some surgeons and hospitals may take self-selection to the extreme of exiting the market for CABG procedures while others invest heavily to raise their skills to a higher level.

Second, our results do not imply that report cards are harmful in general. Indeed, the fact that there is evidence of sorting in the AMI population (against which providers cannot easily select) suggests that report cards could be constructive if designed in a way to minimize the incentives and opportunities for provider selection. One potential problem with the New York and Pennsylvania report cards we analyze is that they require reporting on all patients receiving an elective operative procedure - not on a population of patients who suffer from an illness. Future empirical work should analyze recent state initiatives that use detailed clinical data to report on populations of patients with specific illnesses, in order to investigate if such design changes can address the shortcomings of procedure-based report cards. For example, if the quality of care for AMI patients is correlated with the quality of care for CABG and other types of cardiac patients, then report cards on AMI care may also be helpful for identifying high-quality CABG providers. Future work should also measure if report cards in the long run cause providers to take steps to improve quality, a behavioral response that may dominate the short-run harm that the selection response caused during the period we examine here. Finally, report cards and the incentives they create are not unique to health care. Report cards on the performance of schools raise the same issues and therefore also need careful empirical evaluation.

\section{References}

[1] Bentley, J. Marvin and David B. Nash. 1998. How Pennsylvania Hospitals

supplementary analysis not presented in the tables) other evidence of a decline in the quantity of CABG provided to sicker AMI patients. The prior year's expenditures of AMI patients receiving CABG with a prior year's hospital admission rose everywhere in the U.S. between 1990 and 1994, but rose by approximately half as much in NY and PA (from $\$ 8315$ to $\$ 8793$, or 5.8 percent) as in all other states (from $\$ 7365$ to $\$ 8389$, or 13.9 percent) or as in CT, MD, and NJ (from $\$ 8457$ to $\$ 9334$, or 10.4 percent). 
Have Responded to Publicly Released Reports on Coronary Artery Bypass Graft Surgery. Joint Commission J. of Quality Improvement 24: 40-49.

[2] Capps, Cory, David Dranove, Shane Greenstein, and Mark Satterthwaite. 2001. The Silent Majority Fallacy of the Elzinga-Hogarty Criteria: A Critique and New Approach to Analyzing Hospital Mergers. NBER Working Paper 8216.

[3] Chassin, M., E. Hannan, and B. DeBuono. 1996. Benefits and hazards of reporting medical outcomes publicly. New England J. of Med. 334: 394-98.

[4] Dranove, D. and M. Satterthwaite. 1992. Monopolistic Competition when Price and Quality are not Perfectly Observable. Rand Journal of Economics 23: $518-34$.

[5] Dziuban, S., J. McIlduff, S. Miller, and R. Dal Col. 1994. How a New York cardiac surgery program uses outcomes data. Annals of Thoracic Surgery 58: $1871-76$.

[6] Green, Jesse and Neil Wintfeld. 1995. Report Cards on Cardiac Surgeons Assessing New York State's Approach. New England Journal of Medicine 332: 1229-33.

[7] Hannan, E., H. Kilburn, Jr., M. Racz, E. Shields, M. Chassin. 1994. Improving the outcomes of coronary artery bypass surgery in New York state. J. of Amer. Med. Assoc. 271: 761-766.

[8] Hartz, A., J. Pulido, and E. Kuhn. 1997. Are the best coronary artery bypass surgeons identified by physician surveys. Amer. J. of Public Health 87: $1645-48$.

[9] Hofer, T., R. Hayward, S. Greenfield, E. Wagner, S. Kaplan, and W. Manning. 1999. The unreliability of individual physician " report cards" for assessing the costs and quality of care of a chronic disease. J. of the Amer. Med. Assoc. 281 (9 June): 2098-105.

[10] Ho, M., M. Eisenberg, P. Litwin, S. Schaeffer, and S. Damon. 1989. Delay between onset of chest pain and seeking medical care: The effect of public education. Annals of Emergency Medicine 187: 727-31.

[11] Iezzoni, L. I., ed. 1994. Risk-Adjustment for Measuring Health Care Outcomes. Ann Arbor, MI: Health Administration Press.

[12] Iezzoni, L. I., ed. 1997a. Risk-Adjustment for Measuring Health Care Outcomes. 2d. ed. Chicago, IL: Health Administration Press.

[13] Iezzoni, L. I. 1997b. The Risks of Risk Adjustment. J. of the Amer. Med. Assoc. 278 (19 November): 1600-07. 
[14] Iezzoni, L. I., A. S. Ash, M. Shwartz, B. E. Landon, and Y. D. Mackiernan. 1998. Predicting In-Hospital Deaths from Coronary Artery Bypass Graft Surgery: Do Different Severity Measures Give Different Predictions? Medical Care 36: 28-39.

[15] Kessler, D. P. and M. B. McClellan. 2000. Is hospital competition socially wasteful? Quarterly J. of Economics 115: 577-615.

[16] Kessler, D. P. and M. B. McClellan. 2001. The Effects of Hospital Ownership on Medical Productivity. NBER Working Paper 8537.

[17] Leventis, A. 1997. Cardiac Surgeons Under Scrutiny: A Testable PatientSelection Model. Center for Economic Policy Stuides Working Paper 41, Princeton University.

[18] Localio, A. R., B. H. Hamory, A.C. Fisher, and T. R. TenHave. 1997. The Public Release of Hospital and Physician mortality Data in Pennsylvania: A Case Study. Medical Care 35: 272-286.

[19] Marshall, M. N., P. G. Shekelle, S. Leatherman, and R. H. Brook. 2000. The Public Release of Performance Data: What Do We Expect to Gain? A Review of the Evidence. J. of the Amer. Med. Assoc. 283 (12 April): 1866-74.

[20] Mennemeyer, S. M. Morrisey, and L. Howard. 1997. Death and reputation: How consumers acted upon HCFA mortality data. Inquiry 34: 117-128.

[21] Mukamel, D. and A. Mushlin. 1998. Quality of care information makes a difference: An analysis of market share and price changes after publication of the New York state cardiac surgery mortality reports. Medical Care 36: 945-54.

[22] Pennsylvania Health Care Cost Containment Council. 1992. Coronary artery bypass graft surgery: A technical report. Vol. I, 1990 data. Harrisburg, PA.

[23] Peterson, E. D., E. R. DeLong, J. G. Jollis, L. H. Muhlbaier, and D. B. Mark. 1998. The Effects of New York's Bypass Surgery Provider Profiling on Access to Care and Patient Outcomes in the Elderly. J. of the Am. College of Cardiology 32: 993-99.

[24] Richards, T., B. Blacketer, and D. Rittenhouse. $1994 . \quad$ Statewide, Metropolitan, Corporate, and National Efforts in Monitoring and Reporting Quality of Care. Sacramento, CA: Health Policy and Planning Division, Office of Statewide Health Planning and Development.

[25] Romano, P. S. and B. K. Chan. 2000. Risk-Adjusting Acute Myocardial Infarction Mortality: Are APR-DRGs the Right Tool? Health Services Research 34: 1469-89. 
[26] Romano, P. S., J. A. Rainwater, D. Antonius. 1999. Grading the Graders: How Hospitals in California and New York Perceive and Interpret Their Report Cards. Medical Care 27: 295-305.

[27] Schneider, E. and A. Epstein. 1996. Influence of cardiac-surgery performance reports on referral practices and access to care. New England J. of Med. 335: 251-256.

[28] Schneider, E. and A. Epstein. 1998. Use of Public Performance Reports: A Survey of Patients Undergoing Cardiac Surgery. J. of the Amer. Med. Assoc. 279 (27 May): 1638-42.

[29] Selker, H. P., J. L. Griffith, and R. B. D'Agostino. 1991. A TimeInsensitive Predictive Instrument for Acute Myocardial Infarction Mortality: A Multicenter Study. Medical Care 29: 1196-1211.

[30] Topol, E. and R. Califf. 1994. Scorecard cardiovascular medicine: Its impact and future directions. Annals of Internal Medicine 120: 65-70.

[31] Weintraub, W., E. Jones, J. Craver, R. Grosswald, and R. Guyton. 1995. Inhospital and long-term outcome after reoperative coronary bypass graft surgery. Circulation 92 (Supplement II): 50-57. 
Table 1: Mean Expenditures in Year Prior to Admission for AMI or for CABG Surgery, Elderly Medicare Beneficiaries, 1990 and 1994

\begin{tabular}{lccccccccccc}
\hline & \multicolumn{3}{c}{ All AMI patients } & \multicolumn{3}{c}{$\begin{array}{c}\text { All patients receiving } \\
\text { CABG within 1 year of } \\
\text { Dependent } \\
\text { Variable }\end{array}$} & \multicolumn{1}{c}{ admission } & \multicolumn{3}{c}{$\begin{array}{c}\text { AMI patients receiving } \\
\text { CABG within 1 year of } \\
\text { admission }\end{array}$} \\
& 1990 & 1994 & $\begin{array}{c}\% \\
\text { chg }\end{array}$ & 1990 & 1994 & $\begin{array}{c}\% \\
\text { chg }\end{array}$ & 1990 & 1994 & $\begin{array}{c}\% \\
\text { chg }\end{array}$ \\
NY and PA & $\$ 3110$ & $\$ 3373$ & 0.0846 & $\$ 4850$ & $\$ 4511$ & -0.0699 & $\$ 1867$ & $\$ 1702$ & -0.0883 \\
All other states & 2660 & 2910 & 0.0940 & 3657 & 3660 & 0.0008 & 1537 & 1585 & 0.0312 \\
CT, MD, NJ only & 3055 & 3318 & 0.0861 & 5015 & 4934 & -0.0162 & 1911 & 1859 & -0.0272 \\
\hline
\end{tabular}


Table 2: Effects of Report Cards on the Within-Hospital Coefficient of Variation (CV) and Mean of Patients' Health Status Before Treatment, Medicare Beneficiaries with AMI and Medicare Beneficiaries Receiving CABG, 1987-94

\begin{tabular}{|c|c|c|c|c|}
\hline \multirow[b]{2}{*}{ Dependent Variable } & \multicolumn{2}{|c|}{ Beneficiaries receiving CABG } & \multicolumn{2}{|c|}{ Beneficiaries with AMI } \\
\hline & $\begin{array}{c}\text { Assumes report } \\
\text { cards effective } \\
1991 \text { in NY and } \\
1993 \text { in PA } \\
\end{array}$ & $\begin{array}{c}\text { Assumes report } \\
\text { cards effective } \\
1993 \text { in NY and } \\
\text { PA } \\
\end{array}$ & $\begin{array}{c}\text { Assumes report } \\
\text { cards effective } \\
1991 \text { in NY and } \\
1993 \text { in PA } \\
\end{array}$ & $\begin{array}{c}\text { Assumes report } \\
\text { cards effective } \\
1993 \text { in NY and } \\
\text { PA } \\
\end{array}$ \\
\hline $\begin{array}{l}\text { 1n (Mean of patients' total } \\
\text { hospital expenditures } 1 \text { year } \\
\text { prior to admission) }\end{array}$ & $\begin{array}{c}-3.92 * * \\
(1.54)\end{array}$ & $\begin{array}{c}-5.30 * * \\
(1.28)\end{array}$ & $\begin{array}{l}3.37 * \\
(1.77)\end{array}$ & $\begin{array}{c}1.55 \\
(1.53)\end{array}$ \\
\hline $\begin{array}{l}\text { 1n (Mean of patients' total } \\
\text { days in hospital } 1 \text { year prior } \\
\text { to admission) }\end{array}$ & $\begin{array}{l}-2.43 * * \\
(0.81)\end{array}$ & $\begin{array}{l}-4.51 * * \\
(2.12)\end{array}$ & $\begin{array}{c}1.11 \\
(1.79)\end{array}$ & $\begin{array}{l}1.56 \\
(2.03)\end{array}$ \\
\hline $\begin{array}{l}\text { 1n (CV of patients' total } \\
\text { hospital expenditures } 1 \text { year } \\
\text { prior to admission) }\end{array}$ & $\begin{array}{c}3.00 * * \\
(1.37)\end{array}$ & $\begin{array}{c}3.60 * * \\
(1.38)\end{array}$ & $\begin{array}{c}-2.32 * * \\
(0.81)\end{array}$ & $\begin{array}{c}-2.43 * * \\
(0.81)\end{array}$ \\
\hline $\begin{array}{l}\text { 1n (CV of patients' total days } \\
\text { in hospital } 1 \text { year prior to } \\
\text { admission) }\end{array}$ & $\begin{array}{c}0.94 \\
(2.12)\end{array}$ & $\begin{array}{c}2.74 \\
(2.84)\end{array}$ & $\begin{array}{c}-4.79 * * \\
(1.41)\end{array}$ & $\begin{array}{c}-4.98 * * \\
(1.42)\end{array}$ \\
\hline
\end{tabular}

Notes: Each table entry represents a separate model. Heteroscedasticity-consistent standard errors corrected for within state/time cell correlation in parentheses. Coefficients and standard errors multiplied by 100 to facilitate interpretation. Each observation weighted by the number of patients admitted to the hospital in the cohort in question. *-significantly different from zero at the 10 percent level. **-significantly different from zero at the 5 percent level. Sample sizes: for AMI patients, CV of expenditures $=37,672 ; \mathrm{CV}$ of LOS $=37,681$; mean expenditures $=38,066$; mean of LOS $=38,084$. Regressions also include controls for number of hospitals in state of residence. 
Table 3: Effects of Report Cards for Teaching and All Other Hospitals on the Mean of Patients' Health Status Before Treatment, Medicare Beneficiaries with AMI and Medicare Beneficiaries Receiving CABG, 1987-94

\begin{tabular}{|c|c|c|c|c|}
\hline \multirow[b]{2}{*}{ Dependent Variable } & \multicolumn{2}{|c|}{ Beneficiaries receiving CABG } & \multicolumn{2}{|c|}{ Beneficiaries with AMI } \\
\hline & $\begin{array}{l}\text { Report cards } \\
\text { effective } 1991 \text { in } \\
\text { NY and } 1993 \text { in } \\
\text { PA }\end{array}$ & $\begin{array}{c}\text { (Report card } \\
\text { effective } 1991 \text { in } \\
\text { NY and } 1993 \text { in } \\
\text { PA) * teaching } \\
\text { hospital }\end{array}$ & $\begin{array}{c}\text { Report cards } \\
\text { effective } 1991 \text { in } \\
\text { NY and } 1993 \text { in } \\
\text { PA }\end{array}$ & $\begin{array}{c}\text { (Report card } \\
\text { effective } 1991 \text { in } \\
\text { NY and } 1993 \text { in } \\
\text { PA)* teaching } \\
\text { hospital }\end{array}$ \\
\hline $\begin{array}{l}\text { 1n (Mean of patients' total } \\
\text { hospital expenditures } 1 \text { year } \\
\text { prior to admission) }\end{array}$ & $\begin{array}{c}-18.63 * * \\
(2.85)\end{array}$ & $\begin{array}{c}19.78^{* * *} \\
(2.84)\end{array}$ & $\begin{array}{l}-1.78 \\
(2.66)\end{array}$ & $\begin{array}{c}15.05^{* *} \\
(5.74)\end{array}$ \\
\hline $\begin{array}{l}\text { 1n (Mean of patients' total } \\
\text { days in hospital } 1 \text { year prior } \\
\text { to admission) }\end{array}$ & $\begin{array}{c}-11.38 * * \\
(2.53)\end{array}$ & $\begin{array}{c}10.28 * * \\
(2.41)\end{array}$ & $\begin{array}{l}-2.06 \\
(2.91)\end{array}$ & $\begin{array}{l}9.27 * \\
(4.84)\end{array}$ \\
\hline
\end{tabular}

Notes: Each table entry represents a separate model. Heteroscedasticity-consistent standard errors corrected for within state/time cell correlation in parentheses. Coefficients and standard errors multiplied by 100 to facilitate interpretation. Each observation weighted by the number of patients admitted to the hospital in the cohort in question. *-significantly different from zero at the 10 percent level. **-significantly different from zero at the 5 percent level. Sample size: for CV of expenditures $=37,672$; for $\mathrm{CV}$ of $\operatorname{LOS}=37,681$; for mean expenditures $=$ 38,066; for mean of LOS $=38,084$. Regressions also include controls for number of hospitals in state of residence. 


\section{Table 4: Effects of Report Cards on CABG, PTCA, and Catheterization Rates}

Medicare Beneficiaries with AMI, 1987-94

\begin{tabular}{|c|c|c|c|c|c|c|}
\hline \multirow{2}{*}{$\begin{array}{l}\text { Dependent } \\
\text { Variable } \\
\text { [mean for individuals } \\
\text { without and with a } \\
\text { prior year hospital } \\
\text { admission] }\end{array}$} & \multicolumn{3}{|c|}{$\begin{array}{c}\text { Assumes report cards effective } 1991 \text { in NY } \\
\text { and } 1993 \text { in PA }\end{array}$} & \multicolumn{3}{|c|}{$\begin{array}{l}\text { Assumes report cards effective } 1993 \text { in NY } \\
\text { and PA }\end{array}$} \\
\hline & $\begin{array}{l}\text { Effect of } \\
\text { report cards }\end{array}$ & $\begin{array}{l}\text { Admission } \\
\text { to hospital } \\
\text { in year } \\
\text { before AMI }\end{array}$ & $\begin{array}{l}\text { Report } \\
\text { cards* } \\
\text { prior year } \\
\text { admission }\end{array}$ & $\begin{array}{l}\text { Effect of } \\
\text { report cards }\end{array}$ & $\begin{array}{l}\text { Admission } \\
\text { to hospital } \\
\text { in year } \\
\text { before AMI }\end{array}$ & $\begin{array}{l}\text { Report } \\
\text { cards* } \\
\text { prior year } \\
\text { admission }\end{array}$ \\
\hline $\begin{array}{l}\text { CABG within } 1 \text { year of } \\
\text { admission }(1=\text { yes })\end{array}$ & $\begin{array}{l}0.60 * * \\
(0.28)\end{array}$ & & & $\begin{array}{l}0.91 * * \\
(0.31)\end{array}$ & & \\
\hline$[14.76,9.10]$ & $\begin{array}{l}0.81 * * \\
(0.41)\end{array}$ & $\begin{array}{l}-3.80^{* *} \\
(0.11)\end{array}$ & $\begin{array}{l}-0.65 \\
(0.60)\end{array}$ & $\begin{array}{l}1.39 * * \\
(0.38)\end{array}$ & $\begin{array}{l}-3.78^{* *} \\
(0.11)\end{array}$ & $\begin{array}{l}-1.52 * * \\
(0.46)\end{array}$ \\
\hline $\begin{array}{l}\text { CABG within } 30 \text { days } \\
\text { of admission ( } 1=\text { yes) }\end{array}$ & $\begin{array}{c}0.34 \\
(0.24)\end{array}$ & & & $\begin{array}{l}0.74 * * \\
(0.26)\end{array}$ & & \\
\hline$[11.12,6.52]$ & $\begin{array}{c}0.47 \\
(0.38)\end{array}$ & $\begin{array}{c}-3.21 * * \\
(0.11)\end{array}$ & $\begin{array}{l}-0.36 \\
(0.56)\end{array}$ & $\begin{array}{l}1.13 * * \\
(0.31)\end{array}$ & $\begin{array}{c}-3.18^{* *} \\
(0.11)\end{array}$ & $\begin{array}{c}-1.20 * * \\
(0.38)\end{array}$ \\
\hline $\begin{array}{l}\text { CABG within } 1 \text { day of } \\
\text { admission }(1=\text { yes })\end{array}$ & $\begin{array}{c}-0.78 * * \\
(0.19)\end{array}$ & & & $\begin{array}{l}-0.59 * * \\
(0.20)\end{array}$ & & \\
\hline$[5.40,2.97]$ & $\begin{array}{c}-0.97 * * \\
(0.25)\end{array}$ & $\begin{array}{c}-1.73 * * \\
(0.08)\end{array}$ & $\begin{array}{l}0.72 * * \\
(0.32)\end{array}$ & $\begin{array}{c}-0.66^{* *} \\
(0.26)\end{array}$ & $\begin{array}{c}-1.71 * * \\
(0.08)\end{array}$ & $\begin{array}{c}0.29 \\
(0.29)\end{array}$ \\
\hline $\begin{array}{l}\text { PTCA within } 1 \text { year of } \\
\text { admission }(1=\text { yes })\end{array}$ & $\begin{array}{l}-1.69 * * \\
(0.61)\end{array}$ & & & $\begin{array}{r}-1.22 * \\
(0.70)\end{array}$ & & \\
\hline$[13.94,8.76]$ & $\begin{array}{c}-1.73 * * \\
(0.78)\end{array}$ & $\begin{array}{c}-3.50 * * \\
(0.11)\end{array}$ & $\begin{array}{c}0.23 \\
(0.79)\end{array}$ & $\begin{array}{l}-0.96 \\
(0.90)\end{array}$ & $\begin{array}{c}-3.46^{* *} \\
(0.11)\end{array}$ & $\begin{array}{l}-0.76 \\
(0.77)\end{array}$ \\
\hline $\begin{array}{l}\text { PTCA within } 30 \text { days of } \\
\text { admission ( } 1=\text { yes) }\end{array}$ & $\begin{array}{c}-1.80 * * \\
(0.63)\end{array}$ & & & $\begin{array}{l}-1.25 * \\
(0.71)\end{array}$ & & \\
\hline$[12.35,7.54]$ & $\begin{array}{c}-1.86^{* *} \\
(0.81)\end{array}$ & $\begin{array}{l}-3.30 * * \\
(0.11)\end{array}$ & $\begin{array}{c}0.31 \\
(0.84)\end{array}$ & $\begin{array}{l}-0.99 \\
(0.92)\end{array}$ & $\begin{array}{l}-3.26^{* *} \\
(0.11)\end{array}$ & $\begin{array}{l}-0.79 \\
(0.82)\end{array}$ \\
\hline $\begin{array}{l}\text { PTCA within } 1 \text { day of } \\
\text { admission ( } 1=\text { yes) }\end{array}$ & $\begin{array}{l}-2.21 * * \\
(0.50)\end{array}$ & & & $\begin{array}{l}-2.06 * * \\
(0.58)\end{array}$ & & \\
\hline$[7.81,4.82]$ & $\begin{array}{l}-2.55^{* *} \\
(0.56)\end{array}$ & $\begin{array}{l}-2.05^{* *} \\
(0.08)\end{array}$ & $\begin{array}{l}1.22 * * \\
(0.46)\end{array}$ & $\begin{array}{l}-2.22 * * \\
(0.67)\end{array}$ & $\begin{array}{l}-2.00 * * \\
(0.09)\end{array}$ & $\begin{array}{c}0.59 \\
(0.43)\end{array}$ \\
\hline $\begin{array}{l}\text { Cath within } 1 \text { year of } \\
\text { admission (1=yes) }\end{array}$ & $\begin{array}{l}-0.81 \\
(0.61)\end{array}$ & & & $\begin{array}{c}0.24 \\
(0.47)\end{array}$ & & \\
\hline$[40.65,26.77]$ & $\begin{array}{l}-0.88 \\
(0.93)\end{array}$ & $\begin{array}{c}-9.55^{* *} \\
(0.21)\end{array}$ & $\begin{array}{c}0.48 \\
(1.23)\end{array}$ & $\begin{array}{c}0.72 \\
(0.71)\end{array}$ & $\begin{array}{l}-9.47 * * \\
(0.21)\end{array}$ & $\begin{array}{l}-1.37 \\
(0.97)\end{array}$ \\
\hline $\begin{array}{l}\text { Cath within } 30 \text { days of } \\
\text { admission (1=yes) }\end{array}$ & $\begin{array}{l}-0.66 \\
(0.77)\end{array}$ & & & $\begin{array}{c}0.66 \\
(0.60)\end{array}$ & & \\
\hline$[36.70,23.10]$ & $\begin{array}{l}-0.61 \\
(1.13)\end{array}$ & $\begin{array}{c}-9.53^{* *} \\
(0.23)\end{array}$ & $\begin{array}{c}0.06 \\
(1.37)\end{array}$ & $\begin{array}{l}1.31 \\
(0.91)\end{array}$ & $\begin{array}{c}-9.46^{* *} \\
(0.23)\end{array}$ & $\begin{array}{l}-1.93^{*} \\
(1.15)\end{array}$ \\
\hline $\begin{array}{l}\text { Cath within } 1 \text { day of } \\
\text { admission (1=yes) }\end{array}$ & $\begin{array}{l}-3.75^{* *} \\
(0.85)\end{array}$ & & & $\begin{array}{l}-2.77 * * \\
(0.84)\end{array}$ & & \\
\hline$[26.81,16.25]$ & $\begin{array}{l}-4.28 * * \\
(1.04)\end{array}$ & $\begin{array}{c}-7.54 * * \\
(0.22)\end{array}$ & $\begin{array}{l}2.02 * * \\
(0.99)\end{array}$ & $\begin{array}{c}-2.86 * * \\
(1.02)\end{array}$ & $\begin{array}{c}-7.45 * * \\
(0.22)\end{array}$ & $\begin{array}{c}0.56 \\
(0.85)\end{array}$ \\
\hline
\end{tabular}

Notes: Heteroscedasticity-consistent standard errors corrected for within state/time cell correlation in parentheses. Coefficients and standard errors multiplied by 100 to facilitate interpretation. For expenditures models $\mathrm{N}=$ $1,768,585$; for all other models $\mathrm{N}=1,770,452$. 
Table 5: Effects of Report Cards on Hospital Expenditures and Health Outcomes Medicare Beneficiaries with AMI, 1987-94

\begin{tabular}{|c|c|c|c|c|c|c|}
\hline \multirow{2}{*}{$\begin{array}{l}\text { Dependent } \\
\text { Variable }\end{array}$} & \multicolumn{3}{|c|}{$\begin{array}{c}\text { Assumes report cards effective } 1991 \text { in NY } \\
\text { and } 1993 \text { in PA }\end{array}$} & \multicolumn{3}{|c|}{$\begin{array}{c}\text { Assumes report cards effective } 1993 \text { in NY } \\
\text { and PA }\end{array}$} \\
\hline & $\begin{array}{l}\text { Effect of } \\
\text { report cards }\end{array}$ & $\begin{array}{c}\text { Admission } \\
\text { to hospital } \\
\text { in year } \\
\text { before AMI }\end{array}$ & $\begin{array}{l}\text { Report } \\
\text { cards* } \\
\text { prior year } \\
\text { admission }\end{array}$ & $\begin{array}{l}\text { Effect of } \\
\text { report cards }\end{array}$ & $\begin{array}{l}\text { Admission } \\
\text { to hospital } \\
\text { in year } \\
\text { before AMI }\end{array}$ & $\begin{array}{l}\text { Report } \\
\text { cards* } \\
\text { prior year } \\
\text { admission }\end{array}$ \\
\hline \multirow{2}{*}{$\begin{array}{l}\ln \text { (total hospital } \\
\text { expends in year after } \\
\text { admission) }\end{array}$} & $\begin{array}{l}3.92 * * \\
(1.12)\end{array}$ & & & $\begin{array}{l}3.95 * * \\
(1.15)\end{array}$ & & \\
\hline & $\begin{array}{l}2.89 * \\
(1.12)\end{array}$ & $\begin{array}{l}7.33 * * \\
(0.25)\end{array}$ & $\begin{array}{l}3.35 * * \\
(1.23)\end{array}$ & $\begin{array}{l}3.31 * * \\
(1.06)\end{array}$ & $\begin{array}{l}7.44 * * \\
(0.26)\end{array}$ & $\begin{array}{c}1.93 \\
(1.25)\end{array}$ \\
\hline \multirow{2}{*}{$\begin{array}{l}\text { Readmission with } \\
\text { AMI w/in 1yr of adm } \\
\text { (1=yes) }\end{array}$} & $\begin{array}{c}0.02 \\
(0.10)\end{array}$ & & & $\begin{array}{c}0.06 \\
(0.09)\end{array}$ & & \\
\hline & $\begin{array}{l}-0.15 \\
(0.09)\end{array}$ & $\begin{array}{l}1.70 * * \\
(0.04)\end{array}$ & $\begin{array}{l}0.55^{* *} \\
(0.18)\end{array}$ & $\begin{array}{l}-0.11 \\
(0.10)\end{array}$ & $\begin{array}{l}1.72 * * \\
(0.04)\end{array}$ & $\begin{array}{l}0.52 * * \\
(0.12)\end{array}$ \\
\hline \multirow{2}{*}{$\begin{array}{l}\text { Readmission with HF } \\
\text { w/in } 1 \mathrm{yr} \text { of adm } \\
\text { (1=yes) }\end{array}$} & $\begin{array}{l}0.50 * * \\
(0.13)\end{array}$ & & & $\begin{array}{l}0.54 * * \\
(0.14)\end{array}$ & & \\
\hline & $\begin{array}{l}-0.20 \\
(0.16)\end{array}$ & $\begin{array}{l}4.89 * * \\
(0.07)\end{array}$ & $\begin{array}{l}2.27 * * \\
(0.26)\end{array}$ & $\begin{array}{l}-0.18 \\
(0.19)\end{array}$ & $\begin{array}{l}4.93 * * \\
(0.07)\end{array}$ & $\begin{array}{l}2.30 * * \\
(0.34)\end{array}$ \\
\hline \multirow[t]{2}{*}{$\begin{array}{l}\text { Mortality w/in 1year } \\
\text { of admission (1=yes) }\end{array}$} & $\begin{array}{l}0.45^{*} \\
(0.25)\end{array}$ & & & $\begin{array}{c}0.45 \\
(0.30)\end{array}$ & & \\
\hline & $\begin{array}{c}0.37 \\
(0.29)\end{array}$ & $\begin{array}{c}11.90 * * \\
(0.08)\end{array}$ & $\begin{array}{l}-0.02 \\
(0.47)\end{array}$ & $\begin{array}{c}0.13 \\
(0.33)\end{array}$ & $\begin{array}{c}11.88^{* *} \\
(0.09)\end{array}$ & $\begin{array}{l}0.69 * * \\
(0.28)\end{array}$ \\
\hline
\end{tabular}

Notes: Heteroscedasticity-consistent standard errors corrected for within state/time cell correlation in parentheses. Coefficients and standard errors multiplied by 100 to facilitate interpretation. For expenditures models $\mathrm{N}=$ $1,768,585$; for all other models $\mathrm{N}=1,770,452$. 
Table 6: Alternative Models of Effects of Report Cards on CABG Surgery Rates,

Hospital Expenditures, and Health Outcomes of Individual Medicare Beneficiaries with AMI, 1987-94

\begin{tabular}{|c|c|c|c|c|c|c|}
\hline \multirow{2}{*}{$\begin{array}{l}\text { Dependent } \\
\text { Variable }\end{array}$} & \multicolumn{3}{|c|}{$\begin{array}{l}\text { Hospitals and patients from NY, PA, CT, } \\
\text { MD, NJ only }\end{array}$} & \multicolumn{3}{|c|}{ Linear time trend included for NY and PA } \\
\hline & $\begin{array}{l}\text { Effect of } \\
\text { report cards }\end{array}$ & $\begin{array}{c}\text { Admission } \\
\text { to hospital } \\
\text { in year } \\
\text { before AMI }\end{array}$ & $\begin{array}{l}\text { Report } \\
\text { cards* } \\
\text { prior year } \\
\text { admission }\end{array}$ & $\begin{array}{l}\text { Effect of } \\
\text { report cards }\end{array}$ & $\begin{array}{l}\text { Admission } \\
\text { to hospital } \\
\text { in year } \\
\text { before AMI }\end{array}$ & $\begin{array}{l}\text { Report } \\
\text { cards* } \\
\text { prior year } \\
\text { admission }\end{array}$ \\
\hline \multirow[t]{2}{*}{$\begin{array}{l}\text { CABG within } 1 \text { year } \\
\text { of admission (1=yes) }\end{array}$} & $\begin{array}{c}0.42 \\
(0.28)\end{array}$ & & & $\begin{array}{c}0.27 \\
(0.38)\end{array}$ & & \\
\hline & $\begin{array}{l}0.98 * * \\
(0.39)\end{array}$ & $\begin{array}{l}-2.66 * * \\
(0.31)\end{array}$ & $\begin{array}{l}-1.94 * * \\
(0.69)\end{array}$ & $\begin{array}{c}0.46 \\
(0.48)\end{array}$ & $\begin{array}{l}-3.80 * * \\
(0.11)\end{array}$ & $\begin{array}{l}-0.65 \\
(0.60)\end{array}$ \\
\hline \multirow[t]{2}{*}{$\begin{array}{l}\text { PTCA within } 1 \text { year } \\
\text { of admission (1=yes) }\end{array}$} & $\begin{array}{l}-0.93 * \\
(0.46)\end{array}$ & & & $\begin{array}{c}0.10 \\
(0.68)\end{array}$ & & \\
\hline & $\begin{array}{l}-0.50 \\
(0.63)\end{array}$ & $\begin{array}{l}-2.11 * * \\
(0.29)\end{array}$ & $\begin{array}{l}-1.50^{*} \\
(0.88)\end{array}$ & $\begin{array}{c}0.03 \\
(0.89)\end{array}$ & $\begin{array}{l}-3.50 * * \\
(0.11)\end{array}$ & $\begin{array}{c}0.23 \\
(0.79)\end{array}$ \\
\hline \multirow[t]{2}{*}{$\begin{array}{l}\text { Cath within } 1 \text { day of } \\
\text { admission (1=yes) }\end{array}$} & $\begin{array}{l}-0.76 \\
(0.82)\end{array}$ & & & $\begin{array}{c}0.70 \\
(1.03)\end{array}$ & & \\
\hline & $\begin{array}{l}-0.22 \\
(1.00)\end{array}$ & $\begin{array}{l}-4.63 * * \\
(0.46)\end{array}$ & $\begin{array}{l}-1.87 \\
(1.15)\end{array}$ & $\begin{array}{c}0.10 \\
(1.26)\end{array}$ & $\begin{array}{l}-7.54 * * \\
(0.22)\end{array}$ & $\begin{array}{l}2.01 * * \\
(1.00)\end{array}$ \\
\hline \multirow[t]{2}{*}{$\begin{array}{l}\ln \text { (total hospital } \\
\text { expends in year after } \\
\text { admission) }\end{array}$} & $\begin{array}{l}1.74 \\
(1.43)\end{array}$ & & & $\begin{array}{c}3.49 \\
(2.22)\end{array}$ & & \\
\hline & $\begin{array}{l}1.96 \\
(1.40)\end{array}$ & $\begin{array}{c}10.81 * * \\
(0.57)\end{array}$ & $\begin{array}{l}-0.62 \\
(1.40)\end{array}$ & $\begin{array}{c}2.52 \\
(2.25)\end{array}$ & $\begin{array}{l}7.33 * * \\
(0.25)\end{array}$ & $\begin{array}{c}3.36 \\
(1.23)\end{array}$ \\
\hline \multirow[t]{2}{*}{$\begin{array}{l}\text { Readmission with } \\
\text { AMI w/in 1yr of adm } \\
\text { (1=yes) }\end{array}$} & $\begin{array}{c}0.17 \\
(0.14)\end{array}$ & & & $\begin{array}{l}-0.23 \\
(0.17)\end{array}$ & & \\
\hline & $\begin{array}{c}0.07 \\
(0.14)\end{array}$ & $\begin{array}{l}1.90 * * \\
(0.11)\end{array}$ & $\begin{array}{c}0.35 \\
(0.22)\end{array}$ & $\begin{array}{l}-0.38 * * \\
(0.17)\end{array}$ & $\begin{array}{l}1.70 * * \\
(0.04)\end{array}$ & $\begin{array}{l}0.55^{* *} \\
(0.18)\end{array}$ \\
\hline \multirow{2}{*}{$\begin{array}{l}\text { Readmission with HF } \\
\text { w/in } 1 \mathrm{yr} \text { of adm } \\
\text { (1=yes) }\end{array}$} & $\begin{array}{l}0.41 * * \\
(0.14)\end{array}$ & & & $\begin{array}{c}0.01 \\
(0.20)\end{array}$ & & \\
\hline & $\begin{array}{l}-0.04 \\
(0.17)\end{array}$ & $\begin{array}{l}5.52 * * \\
(0.14)\end{array}$ & $\begin{array}{l}1.57 * * \\
(0.29)\end{array}$ & $\begin{array}{l}-0.64 * * \\
(0.21)\end{array}$ & $\begin{array}{l}4.89 * * \\
(0.07)\end{array}$ & $\begin{array}{l}2.27 * * \\
(0.26)\end{array}$ \\
\hline \multirow[t]{2}{*}{$\begin{array}{l}\text { Mortality w/in 1year } \\
\text { of admission (1=yes) }\end{array}$} & $\begin{array}{l}0.44^{*} \\
(0.26)\end{array}$ & & & $\begin{array}{c}0.10 \\
(0.31)\end{array}$ & & \\
\hline & $\begin{array}{l}0.51 * * \\
(0.25)\end{array}$ & $\begin{array}{c}12.05^{* * *} \\
(0.23)\end{array}$ & $\begin{array}{l}-0.11 \\
(0.53)\end{array}$ & $\begin{array}{c}0.13 \\
(0.35)\end{array}$ & $\begin{array}{l}11.90^{* * *} \\
(0.09)\end{array}$ & $\begin{array}{l}-0.02 \\
(0.47)\end{array}$ \\
\hline
\end{tabular}

Notes: Models assume report cards effective 1991 in NY and 1993 in PA. Heteroscedasticity-consistent standard errors corrected for within state/time cell correlation in parentheses. Coefficients and standard errors multiplied by 100 to facilitate interpretation. For expenditures models in left panel $\mathrm{N}=366,823$; for all other models in left panel $\mathrm{N}=367,421$. For expenditures models in right panel $\mathrm{N}=1,768,585$; for all other models in right panel $\mathrm{N}=$ $1,770,452$. 


\section{Table 7: Effects of Report Cards on Total Hospital Expenditures and Health Outcomes of}

Individual Medicare Beneficiaries Receiving CABG Surgery, 1987-94

\begin{tabular}{|c|c|c|c|c|c|c|}
\hline \multirow[b]{2}{*}{$\begin{array}{l}\text { Dependent } \\
\text { Variable }\end{array}$} & \multicolumn{3}{|c|}{$\begin{array}{c}\text { Assumes report cards effective } 1991 \text { in NY } \\
\text { and } 1993 \text { in PA }\end{array}$} & \multicolumn{3}{|c|}{$\begin{array}{c}\text { Assumes report cards effective } 1993 \text { in NY } \\
\text { and PA }\end{array}$} \\
\hline & $\begin{array}{l}\text { Effect of } \\
\text { report cards }\end{array}$ & $\begin{array}{l}\text { Admission } \\
\text { to hospital } \\
\text { in year } \\
\text { before AMI }\end{array}$ & $\begin{array}{l}\text { Report } \\
\text { cards* } \\
\text { prior year } \\
\text { admission }\end{array}$ & $\begin{array}{l}\text { Effect of } \\
\text { report cards }\end{array}$ & $\begin{array}{l}\text { Admission } \\
\text { to hospital } \\
\text { in year } \\
\text { before AMI }\end{array}$ & $\begin{array}{l}\text { Report } \\
\text { cards* } \\
\text { prior year } \\
\text { admission }\end{array}$ \\
\hline \multirow{2}{*}{$\begin{array}{l}\ln (\text { total hospital } \\
\text { expends in year after } \\
\text { admission) }\end{array}$} & $\begin{array}{l}8.28 * * \\
(1.93)\end{array}$ & & & $\begin{array}{l}5.93 * * \\
(1.82)\end{array}$ & & \\
\hline & $\begin{array}{l}7.08 * * \\
(1.98)\end{array}$ & $\begin{array}{l}2.48 * * \\
(0.22)\end{array}$ & $\begin{array}{r}2.72 * * \\
(0.53)\end{array}$ & $\begin{array}{l}4.76^{* *} \\
(1.82)\end{array}$ & $\begin{array}{l}2.52 * * \\
(0.22)\end{array}$ & $\begin{array}{l}2.80 * * \\
(0.57)\end{array}$ \\
\hline \multirow{2}{*}{$\begin{array}{l}\text { Readmission with } \\
\text { AMI w/in } 1 \mathrm{yr} \text { of adm } \\
\text { (1=yes) }\end{array}$} & $\begin{array}{l}-0.10^{*} \\
(0.06)\end{array}$ & & & $\begin{array}{l}-0.17 * * \\
(0.05)\end{array}$ & & \\
\hline & $\begin{array}{l}-0.15^{*} \\
(0.06)\end{array}$ & $\begin{array}{l}0.22 * * \\
(0.02)\end{array}$ & $\begin{array}{c}0.10 \\
(0.08)\end{array}$ & $\begin{array}{l}-0.17 * * \\
(0.06)\end{array}$ & $\begin{array}{l}0.23 * * \\
(0.02)\end{array}$ & $\begin{array}{c}0.00 \\
(0.09)\end{array}$ \\
\hline \multirow{2}{*}{$\begin{array}{l}\text { Readmission with HF } \\
\text { w/in } 1 \text { yr of adm } \\
\text { (1=yes) }\end{array}$} & $\begin{array}{c}0.14 \\
(0.18)\end{array}$ & & & $\begin{array}{c}0.31 \\
(0.21)\end{array}$ & & \\
\hline & $\begin{array}{l}-0.01 \\
(0.19)\end{array}$ & $\begin{array}{l}3.47 * * \\
(0.06)\end{array}$ & $\begin{array}{c}0.42 \\
(0.32)\end{array}$ & $\begin{array}{c}0.02 \\
(0.21)\end{array}$ & $\begin{array}{l}3.46^{* *} \\
(0.06)\end{array}$ & $\begin{array}{l}0.86^{* *} \\
(0.33)\end{array}$ \\
\hline \multirow[t]{2}{*}{$\begin{array}{l}\text { Mortality w/in 1year } \\
\text { of admission (1=yes) }\end{array}$} & $\begin{array}{l}-1.17 * * \\
(0.21)\end{array}$ & & & $\begin{array}{l}-1.02 * * \\
(0.27)\end{array}$ & & \\
\hline & $\begin{array}{c}-1.02 * * \\
(0.26)\end{array}$ & $\begin{array}{l}2.72 * * \\
(0.09)\end{array}$ & $\begin{array}{l}-0.24 \\
(0.23)\end{array}$ & $\begin{array}{c}-0.86^{* *} \\
(0.36)\end{array}$ & $\begin{array}{l}2.72 * * \\
(0.09)\end{array}$ & $\begin{array}{l}-0.21 \\
(0.30)\end{array}$ \\
\hline
\end{tabular}


Appendix Table 1: Descriptive Statistics on Hospitals

\begin{tabular}{|c|c|c|c|c|}
\hline & \multicolumn{2}{|c|}{$\begin{array}{l}\text { Weighted by and using health histories of } \\
\text { AMI patients }\end{array}$} & \multicolumn{2}{|c|}{$\begin{array}{l}\text { Weighted by and using health histories of } \\
\text { CABG patients }\end{array}$} \\
\hline & 1987 & 1994 & 1987 & 1994 \\
\hline $\begin{array}{l}\mathrm{CV} \text { of patients' total } \\
\text { hospital expenditures } \\
1 \mathrm{yr} \text { prior to admission }\end{array}$ & $\begin{array}{c}2.199 \\
(0.445)\end{array}$ & $\begin{array}{l}2.166 \\
(0.587)\end{array}$ & $\begin{array}{c}1.556 \\
(0.351)\end{array}$ & $\begin{array}{c}1.934 \\
(0.281)\end{array}$ \\
\hline $\begin{array}{l}\mathrm{CV} \text { of patients' total } \\
\text { days in hospital } 1 \mathrm{yr} \\
\text { prior to admission }\end{array}$ & $\begin{array}{c}2.439 \\
(0.574)\end{array}$ & $\begin{array}{c}2.473 \\
(0.751)\end{array}$ & $\begin{array}{l}1.699 \\
(0.294)\end{array}$ & $\begin{array}{c}2.245 \\
(0.418)\end{array}$ \\
\hline $\begin{array}{l}\text { Number of hospitals } \\
\text { in the state }\end{array}$ & 180.3 & 157.7 & 31.58 & 36.52 \\
\hline $\begin{array}{l}\text { Hospital size medium } \\
(1=\text { yes })\end{array}$ & $49.7 \%$ & $51.9 \%$ & $35.8 \%$ & $46.5 \%$ \\
\hline Hospital size large & $25.3 \%$ & $20.9 \%$ & $63.8 \%$ & $51.0 \%$ \\
\hline Teaching hospital & $19.1 \%$ & $20.5 \%$ & $46.2 \%$ & $44.1 \%$ \\
\hline Public ownership & $15.7 \%$ & $13.3 \%$ & $10.1 \%$ & $8.7 \%$ \\
\hline For-profit ownership & $10.4 \%$ & $10.1 \%$ & $7.5 \%$ & $8.4 \%$ \\
\hline Rural location & $26.4 \%$ & $24.5 \%$ & $2.7 \%$ & $3.8 \%$ \\
\hline Subject to report cards & 0.00 & $14.2 \%$ & 0.00 & $13.5 \%$ \\
\hline Sample size & $\begin{array}{c}5,369 \\
(5,077 \text { with CV) }\end{array}$ & $\begin{array}{c}\text { 4,792 (4,389 with } \\
\text { CV) }\end{array}$ & 739 (714 with CV) & 936 (922 with CV) \\
\hline
\end{tabular}

Notes: Hospital expenditures in 1995 dollars. 
Appendix Table 2: Descriptive Statistics on Elderly Medicare Beneficiaries with AMI and Elderly Medicare Beneficiaries Receiving CABG Surgery

\begin{tabular}{|c|c|c|c|c|}
\hline & \multicolumn{2}{|c|}{ With AMI } & \multicolumn{2}{|c|}{ Receiving CABG surgery } \\
\hline & 1987 & 1994 & 1987 & 1994 \\
\hline $\begin{array}{l}\text { Total hospital } \\
\text { expenditures } 1 \text { year } \\
\text { prior to admission }\end{array}$ & $\begin{array}{l}\$ 2,690 \\
(6,493)\end{array}$ & $\begin{array}{l}\$ 2,977 \\
(7,464)\end{array}$ & $\begin{array}{l}\$ 4,431 \\
(7,188)\end{array}$ & $\begin{array}{l}\$ 3,771 \\
(7,586)\end{array}$ \\
\hline $\begin{array}{l}\text { Total days in hospital } \\
1 \text { year prior to } \\
\text { admission }\end{array}$ & $\begin{array}{c}4.21 \\
(11.48)\end{array}$ & $\begin{array}{c}4.22 \\
(13.48)\end{array}$ & $\begin{array}{c}4.97 \\
(8.63)\end{array}$ & $\begin{array}{c}3.39 \\
(8.05)\end{array}$ \\
\hline $\begin{array}{l}\text { Total hospital } \\
\text { expenditures in } 1 \\
\text { year after admission }\end{array}$ & $\begin{array}{l}\$ 14,634 \\
(13,381)\end{array}$ & $\begin{array}{l}\$ 18,959 \\
(19,060)\end{array}$ & $\begin{array}{l}\$ 30,226 \\
(13,857)\end{array}$ & $\begin{array}{l}\$ 34,474 \\
(22,460)\end{array}$ \\
\hline $\begin{array}{l}\text { CABG w/in } 1 \text { year of } \\
\text { admission (1=yes) }\end{array}$ & $9.2 \%$ & $16.2 \%$ & $100 \%$ & $100 \%$ \\
\hline $\begin{array}{l}\text { Readmission w/AMI } \\
\text { w/in } 1 \mathrm{yr} \text { of adm }\end{array}$ & $5.8 \%$ & $5.5 \%$ & $1.1 \%$ & $1.2 \%$ \\
\hline $\begin{array}{l}\text { Readmission with } \\
\text { HF w/in } 1 \mathrm{yr} \text { of adm }\end{array}$ & $9.0 \%$ & $9.4 \%$ & $6.1 \%$ & $6.6 \%$ \\
\hline $\begin{array}{l}\text { Mortality w/in 1year } \\
\text { of admission }\end{array}$ & $40.2 \%$ & $32.9 \%$ & $12.2 \%$ & $10.7 \%$ \\
\hline Age & 76.0 & $76.4 \%$ & 71.39 & 72.54 \\
\hline Gender ( $1=$ female $)$ & $49.8 \%$ & $48.7 \%$ & $34.2 \%$ & $34.7 \%$ \\
\hline Race (1=black) & $5.5 \%$ & $5.9 \%$ & $2.4 \%$ & $3.4 \%$ \\
\hline Rural residence & $30.0 \%$ & $30.9 \%$ & $28.1 \%$ & $29.0 \%$ \\
\hline Sample size & 218,641 & 229,215 & 88,457 & 146,986 \\
\hline
\end{tabular}

Notes: Hospital expenditures in 1995 dollars. For full sample 1987-1994, sample size is 1,770,452 for AMI patients and 967,882 for CABG patients. 